\title{
Calculation and measurement of ampacity for class 5 flexible aluminum cable at $110{ }^{\circ} \mathrm{C}$
}

\author{
Fernando Agustin ${ }^{1}$, Akhtar Kalam², Aladin Zayegh ${ }^{3}$ \\ ${ }^{1,2.3}$ College of Engineering and Science, Victoria University, Victoria, Australia \\ ${ }^{2}$ Head of External Engagement, Leader-Smart Energy Research Unit, Victoria University, Australia
}

\section{Article Info \\ Article history: \\ Received Aug 26, 2020 \\ Revised Dec 16, 2020 \\ Accepted Feb 22, 2021}

\section{Keywords:}

Cable ampacity

Conductor temperature

Flexible aluminum conductor

Heat dissipation

Shear bolt connector

Thermal expansion

\begin{abstract}
Class 5 flexible aluminum conductors are not common in cable manufacturing industry due to insufficient study on cable joints and connectors. The table of ampacities for aluminum conductors at $110{ }^{\circ} \mathrm{C}$ in AS/NZS3008.1.1 standards are also not available as a reference guide for electrical system designers that restricts the installation of aluminum low voltage (LV) cabling system to operate at $90{ }^{\circ} \mathrm{C}$ of conductor maximum operating temperature where $110{ }^{\circ} \mathrm{C}$ cables are permitted in Australia. In this paper, the cable ampacities of various LV Class 5 flexible aluminum cables at maximum operating temperature of $110{ }^{\circ} \mathrm{C}$ are calculated using IEC60287 and AS/NZ3008.1.1 standards. The calculated ampacities from the formula presented in clause 4.4. of AS/NZS3008.1.1 are verified by using the 6kA inductive current generator to determine the suitability for use. The joint temperature between cable and shear bolt mechanical connectors are simultaneoulsy simulated using the calculated ampacities to determine the suitability of mechanical shear bolt connectors when the coefficient of thermal expansion of material is considered. The observed differences between the calculated and measured values demonstrate the relevance of formula used in determining the current ampacity at $110{ }^{\circ} \mathrm{C}$ conductor temperature in free air.
\end{abstract}

This is an open access article under the $\underline{C C B Y-S A}$ license.

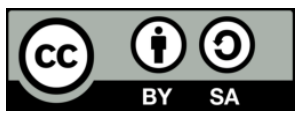

\section{Corresponding Author:}

Fernando Agustin

College of Engineering and Science

Victoria University

Ballarat Road, Footscray 3011, Victoria, Australia

Email: fernando.agustin@live.vu.edu.au

\section{INTRODUCTION}

Class 2 stranded aluminum and copper are the commonly used conductors in power system network. The low resistivity and cost of these materials make them very logical choice of metal for use in power cable industry. Annealed copper has a resistivity of $17.24 \mathrm{n} \Omega \mathrm{m}$ at $20{ }^{\circ} \mathrm{C}$ whereas aluminum has $28.03 \mathrm{n} \Omega \mathrm{m}$. The resistivity of aluminum translates to $61.2 \%$ conductivity of that of copper which means that the crosssectional area of aluminum shall be 1.6 times of Copper to have the same conductor resistance [1]. Moreover, the density of aluminum is less than one-third of Copper that makes aluminum the very cost-effective cable solution for the power industry [2].

Conductor types can be solid, stranded or flexible and can be circular, compacted and sectioned [3], [4]. The most common type of conductors for LV application are the stranded and flexible conductors. Flexible conductors are common in Copper material due to its superior tensile strength over aluminum and can either be Class 5 or 6 depending on the number of wires in conductor construction. Studies are currently 
being done by the author in the implementation of high temperature aluminum cable with flexible conductor construction in LV power industry as presented in Table 1. There are also various studies in the use of high temperature superconductive (HTS) cable in the power utility network conducted by Al-Khalidi, et al. that could enhance the reliability of power networks [5], [6].

Table 1. Typical construction of class 5 flexible aluminum conductor taking into consideration the DC

\begin{tabular}{cccc}
\multicolumn{4}{c}{ resistance of class 2 conductor } \\
\hline $\begin{array}{c}\text { Cross-sectional } \\
\text { area }(\mathrm{CSA}) \\
\left(\mathrm{mm}^{2}\right)\end{array}$ & $\begin{array}{c}\text { Total number } \\
\text { of wires }\end{array}$ & $\begin{array}{c}\text { Diameter of } \\
\text { individual wire } \\
(\mathrm{mm})\end{array}$ & $\begin{array}{c}\text { Maximum DC } \\
\text { resistance at } 20{ }^{\circ} \mathrm{C} \\
(\Omega / \mathrm{km})\end{array}$ \\
\hline 16 & 90 & 0.5 & 1.9100 \\
25 & 133 & 0.5 & 0.1200 \\
35 & 182 & 0.5 & 0.8680 \\
50 & 231 & 0.5 & 0.6410 \\
70 & 361 & 0.5 & 0.4430 \\
95 & 494 & 0.5 & 0.3200 \\
120 & 627 & 0.5 & 0.2530 \\
150 & 760 & 0.5 & 0.2060 \\
185 & 924 & 0.5 & 0.1640 \\
240 & 1221 & 0.5 & 0.1250 \\
300 & 1520 & 0.5 & 0.1000 \\
400 & 2013 & 0.5 & 0.0778 \\
500 & 1792 & 0.6 & 0.0605 \\
630 & 2280 & 0.6 & 0.0469 \\
800 & 2912 & 0.6 & 0.0367 \\
1000 & 3640 & 0.6 & 0.0291 \\
\hline
\end{tabular}

The operating temperature of cabling system affects the choice and type of cable used in electrical power installation. For LV long route installation, the $90{ }^{\circ} \mathrm{C}$ rated cables are always utilized whereas the $110{ }^{\circ} \mathrm{C}$ rated cables are used for higher ampacity load and short distances. Voltage drop is very essential in cable sizing calculation.

AS/NZS3008.1.1 provides the guidelines in cable selection with respect to the temperature rating of insulation and cable. This standard specifies the ampacity ratings for both Copper and aluminum conductors. However, there are no available ampacity rating tables for aluminum cables at $110{ }^{\circ} \mathrm{C}$ operating temperature [7]. The absence of ampacity ratings for aluminum cable at higher temperature limits the opportunity to further reduce the cost of the cabling system and therefore this paper focuses on the study, calculation, and simulation of ampacity of class 5 flexible aluminum cables at higher temperature. The proposed ampacity values can then be utlized by the electrical system designers as a reference guide to reduce the cost of cabling system while still maintaining the reliability of power network.

The reliability of connection is an on-going issue for aluminum conductors due to higher coefficient of thermal expansion of aluminum compared to Copper. There are several studies that have been conducted on the reliability of aluminum cable connection [8]-[14]. The thermal behaviour of class 5 flexible aluminum conductors and mechanical shear bolt connectors are also investigated and evaluated to determine the heat dissipated on insulation, sheath, and cable termination points. The study also aims to identify the suitable connectors for class 5 flexible aluminum conductors.

\section{THERMOMECHANICAL CONSIDERATION}

Cables are subjected to cyclic loads during operaton hence, experience temperature variations and the effect of which depend on manner of installation categorized into two extreme cases; completely unrestricted and fully restrained. For the completely unrestricted case, the cable experiences expansion with the change in length primarily differd by coefficient of thermal deformation [15] and can be calculated using (1).

$$
\Delta \ell=\alpha \ell_{0} \Delta T
$$

where $\ell$ is the length, $T$ is the temperature, $\alpha$ is the coefficient of thermal expansion $\left({ }^{\circ} \mathrm{C}\right)^{-1}$ $\alpha=25 \times 10^{-6}\left({ }^{\circ} \mathrm{C}\right)^{-1}$ for aluminum

$\alpha=17 \times 10^{-6}\left({ }^{\circ} \mathrm{C}\right)^{-1}$ for Copper 
Hence for the same length and temperature variation, the thermal deformation of aluminum is greater than Copper by about $47 \%$. For the fully restrained case, the cable experiences thermomechanical force in the longitudinal direction which can be calculated using (2).

$$
F=E A \alpha \Delta T
$$

Where $F$ is the thermomechanical force in the conductor, $E$ is the modulus elasticity of conductor, and $A$ is the conductor cross-sectional area. Jointly considering these three parameters for the same temperature variation, Aluminium experiences 30 to $70 \%$ more thermomechanical force than Copper. Furthermore, maintaining a similar property of metallic termination is very important to the reliability of connection. Cables are subjected to cyclic load throughout its service life and poor contact due to stress relaxation which increases the resistance at the termination point could led to failure and overheating of termination. Thermomechanical design when used to limit the differential movement of the connection is also very important in achieving negligible expansion at the termination point [16].

\section{DETERMINATION OF AMPACITY RATING}

The formulae, methods, and standards used in this paper to determine the cable ampacities of class 5 flexible aluminum cables at higher temperature are presented in IEC60287 and clause 4.4 of AS/NZS3008.1.1. The formulae given in IEC60287 consider the construction of conductors, thermal resistivity of insulating material and the parameters related to the surrounding conditions such as the trefoil formation in free air whereas AS/NZS3008.1.1 is a straightforward derivation when the initial rated ampacities are known.

\subsection{Conductor resistance of class 5 flexible aluminum}

The DC and AC resistance per unit length of the conductor at various operating temperature are calculated using (3) and (4). Tables 2 and 3 summarize the conductor resistance results from the calculation.

$$
\begin{aligned}
& R=R^{\prime}\left(1+y_{s}+y_{p}\right) \\
& R^{\prime}=R_{0}\left[1+\alpha_{20}(\theta-20)\right.
\end{aligned}
$$

where $R$ is the AC resistance of conductor at maximum operating temperature $(\Omega / \mathrm{m}), R$ 'is the DC resistance of conductor at maximum operating temperature $(\Omega / \mathrm{m}), y_{s}$ is the skin effect factor, $y_{p}$ is the proximity effect factor, $R_{0}$ is the DC resistance of conductor at $20{ }^{\circ} \mathrm{C}(\Omega / \mathrm{m}), \alpha_{20}$ is the constant mass temperature coefficient and $\theta$ is the maximum operating temperature [17].

Table 2. Calculated AC resistance of conductor

\begin{tabular}{ccccccccccc}
\hline \multirow{2}{*}{$\mathrm{CSA}\left(\mathrm{mm}^{2}\right)$} & \multicolumn{8}{c}{$\mathrm{AC}$ resistance $(\Omega / \mathrm{km})$} \\
\hline 16 & 1.910 & $25{ }^{\circ} \mathrm{C}$ & $40{ }^{\circ} \mathrm{C}$ & $50{ }^{\circ} \mathrm{C}$ & $60{ }^{\circ} \mathrm{C}$ & $70{ }^{\circ} \mathrm{C}$ & $80{ }^{\circ} \mathrm{C}$ & $90{ }^{\circ} \mathrm{C}$ & $100{ }^{\circ} \mathrm{C}$ & $110{ }^{\circ} \mathrm{C}$ \\
\hline 25 & 1.200 & 1.224 & 1.294 & 2.141 & 2.218 & 2.295 & 2.372 & 2.449 & 2.526 & 2.603 \\
35 & 0.868 & 0.886 & 0.938 & 0.973 & 1.394 & 1.442 & 1.490 & 1.539 & 1.587 & 1.635 \\
50 & 0.641 & 0.654 & 0.693 & 0.719 & 0.745 & 0.773 & 1.078 & 1.113 & 1.148 & 1.183 \\
70 & 0.444 & 0.453 & 0.479 & 0.497 & 0.515 & 0.533 & 0.551 & 0.856 & 0.848 & 0.874 \\
95 & 0.321 & 0.327 & 0.347 & 0.359 & 0.372 & 0.385 & 0.398 & 0.411 & 0.424 & 0.604 \\
120 & 0.254 & 0.259 & 0.274 & 0.285 & 0.295 & 0.305 & 0.315 & 0.325 & 0.335 & 0.346 \\
150 & 0.207 & 0.212 & 0.224 & 0.232 & 0.240 & 0.249 & 0.257 & 0.265 & 0.273 & 0.282 \\
185 & 0.166 & 0.169 & 0.179 & 0.185 & 0.192 & 0.199 & 0.205 & 0.212 & 0.218 & 0.225 \\
240 & 0.127 & 0.130 & 0.137 & 0.142 & 0.147 & 0.152 & 0.157 & 0.162 & 0.167 & 0.172 \\
300 & 0.103 & 0.105 & 0.111 & 0.115 & 0.119 & 0.123 & 0.127 & 0.131 & 0.134 & 0.138 \\
400 & 0.082 & 0.083 & 0.088 & 0.091 & 0.094 & 0.097 & 0.100 & 0.103 & 0.106 & 0.109 \\
500 & 0.065 & 0.066 & 0.070 & 0.072 & 0.074 & 0.077 & 0.079 & 0.081 & 0.084 & 0.086 \\
630 & 0.053 & 0.054 & 0.056 & 0.058 & 0.060 & 0.062 & 0.063 & 0.065 & 0.067 & 0.069 \\
800 & 0.044 & 0.045 & 0.047 & 0.048 & 0.049 & 0.050 & 0.052 & 0.053 & 0.054 & 0.056 \\
\hline
\end{tabular}


Table 3. Calculated DC resistance of conductor

\begin{tabular}{ccccccccccc}
\hline \multirow{2}{*}{$\mathrm{CSA}\left(\mathrm{mm}^{2}\right)$} & \multicolumn{8}{c}{ DC resistance $(\Omega / \mathrm{km})$} \\
& $20{ }^{\circ} \mathrm{C}$ & $25{ }^{\circ} \mathrm{C}$ & $40{ }^{\circ} \mathrm{C}$ & $50{ }^{\circ} \mathrm{C}$ & $60{ }^{\circ} \mathrm{C}$ & $70{ }^{\circ} \mathrm{C}$ & $80{ }^{\circ} \mathrm{C}$ & $90{ }^{\circ} \mathrm{C}$ & $100{ }^{\circ} \mathrm{C}$ & $110{ }^{\circ} \mathrm{C}$ \\
\hline 16 & 1.910 & 1.948 & 2.064 & 2.141 & 2.218 & 2.295 & 2.372 & 2.449 & 2.526 & 2.603 \\
25 & 1.200 & 1.224 & 1.297 & 1.345 & 1.393 & 1.442 & 1.490 & 1.539 & 1.587 & 1.635 \\
35 & 0.868 & 0.885 & 0.938 & 0.973 & 1.008 & 1.043 & 1.078 & 1.113 & 1.148 & 1.183 \\
50 & 0.641 & 0.654 & 0.693 & 0.718 & 0.744 & 0.770 & 0.796 & 0.820 & 0.848 & 0.873 \\
70 & 0.443 & 0.452 & 0.479 & 0.497 & 0.514 & 0.532 & 0.550 & 0.568 & 0.586 & 0.604 \\
95 & 0.320 & 0.326 & 0.346 & 0.359 & 0.372 & 0.384 & 0.397 & 0.410 & 0.423 & 0.436 \\
120 & 0.253 & 0.258 & 0.273 & 0.284 & 0.294 & 0.304 & 0.314 & 0.324 & 0.335 & 0.345 \\
150 & 0.206 & 0.210 & 0.223 & 0.231 & 0.239 & 0.248 & 0.256 & 0.264 & 0.272 & 0.281 \\
185 & 0.164 & 0.167 & 0.177 & 0.184 & 0.190 & 0.197 & 0.204 & 0.210 & 0.217 & 0.223 \\
240 & 0.125 & 0.128 & 0.135 & 0.14 & 0.145 & 0.150 & 0.155 & 0.160 & 0.165 & 0.170 \\
300 & 0.100 & 0.102 & 0.108 & 0.112 & 0.116 & 0.120 & 0.124 & 0.128 & 0.132 & 0.136 \\
400 & 0.078 & 0.079 & 0.084 & 0.087 & 0.090 & 0.093 & 0.097 & 0.100 & 0.103 & 0.106 \\
500 & 0.061 & 0.062 & 0.065 & 0.068 & 0.070 & 0.073 & 0.075 & 0.078 & 0.080 & 0.082 \\
630 & 0.047 & 0.048 & 0.051 & 0.053 & 0.054 & 0.056 & 0.058 & 0.060 & 0.062 & 0.064 \\
800 & 0.037 & 0.037 & 0.040 & 0.041 & 0.043 & 0.044 & 0.046 & 0.047 & 0.049 & 0.050 \\
\hline
\end{tabular}

\subsection{Calculation of dielectric losses}

The thermal resistivity of insulating material and the associated wall thickness influence the heat dissipated to the surrounding layers. This energy loss is called dielectric loss and can be calculated using (5) and (6). Table 4 summarizes the calculated dielectric loss of the samples.

$$
W_{d}=\omega C U_{o}^{2} \tan \delta(\mathrm{W} / \mathrm{m})
$$

where $W_{d}$ is the dielectric loss, $\omega$ is equal to $2 \pi \mathrm{f}, C$ is the capacitance per unit length, $U_{O}$ is the voltage to earth (V). $C$ is calculated using (5).

$$
C=\frac{\varepsilon}{18 \ln \left(\frac{D_{i}}{d_{c}}\right)} 10^{-9}(F / m)
$$

where $\varepsilon$ is the relative permittivity of insulation, which is 3.0 for X-HF-110, $D_{i}$ is the external diameter of insulation, $d_{c}$ is the diameter of conductor [17].

Table 4. Calculated dielectric loss

\begin{tabular}{cc}
\hline $\mathrm{CSA}\left(\mathrm{mm}^{2}\right)$ & $\mathrm{W}_{\mathrm{d}}(\mathrm{W} / \mathrm{m})$ \\
\hline 16 & 0.00025 \\
25 & 0.00027 \\
35 & 0.00031 \\
50 & 0.00035 \\
70 & 0.00036 \\
95 & 0.00042 \\
120 & 0.00043 \\
150 & 0.00041 \\
185 & 0.00040 \\
240 & 0.00042 \\
300 & 0.00045 \\
400 & 0.00046 \\
500 & 0.00049 \\
630 & 0.00050 \\
800 & 0.00056 \\
\hline
\end{tabular}

\subsection{Calculation of thermal resistance $\mathrm{T} 1, \mathrm{~T} 4$ and rated ampacities}

The thermal resistance $T_{1}$ between one conductor and sheath, and the external thermal resistance $T_{4}$ are calculated using (7) and (8), respectively. Table 5 summarizes the calculated values of $\mathrm{T}_{1}$ and $\mathrm{T}_{4}$. Cable samples are LV single-core double insulated (SDI) without metallic coverings and therefore $\mathrm{T}_{2}$ and $\mathrm{T}_{3}$ are being neglected.

$$
\begin{aligned}
& T_{1}=\frac{\rho_{T}}{2 \pi} \ln \left[1+\frac{2 t_{1}}{d_{c}}\right] \\
& T_{4}=\frac{1}{\pi D_{e} h\left(\Delta \theta_{S}\right)^{1 / 4}}
\end{aligned}
$$




$$
h=\frac{Z}{\left(D_{e}^{*}\right)^{g}}+E
$$

where $\rho_{T}$ is the thermal resistivity of X-HF-110 insulation $(\mathrm{K} . \mathrm{m} / \mathrm{W}) ; t_{l}$ is the thickness of insulation between conductor and sheath $(\mathrm{mm}) ; d_{c}$ is the diameter of conductor $(\mathrm{mm}) ; h$ is the heat dissipation; $\mathrm{Z}, \mathrm{E}$ and $\mathrm{g}$ are constant; $D_{e}$ is the external diameter of cable $(\mathrm{m})$ and $\Delta \theta_{s}$ is the excess cable temperature above ambient temperature [17], [18].

Table 5. Calculated thermal resistance $\mathrm{T}_{1}$ and $\mathrm{T}_{4}$

\begin{tabular}{ccccccccc}
\hline $\begin{array}{c}\text { CSA } \\
\mathrm{mm}^{2}\end{array}$ & $\mathrm{~T}_{\mathrm{I}}$ & $\begin{array}{c}\mathrm{D}_{\mathrm{e}} \\
\mathrm{m}\end{array}$ & $\mathrm{Z}$ & $\mathrm{E}$ & $\mathrm{g}$ & $\mathrm{h}$ & $\begin{array}{c}\text { KA } \\
\mathrm{n}=3\end{array}$ & $\mathrm{~T}_{4}$ in Air \\
\hline 16 & 0.3851 & 0.0099 & 0.96 & 1.25 & 0.2 & 3.664 & 0.0441 & 6.112 \\
25 & 0.3913 & 0.0120 & 0.96 & 1.25 & 0.2 & 3.573 & 0.0176 & 5.172 \\
35 & 0.3437 & 0.0133 & 0.96 & 1.25 & 0.2 & 3.526 & 0.0169 & 4.731 \\
50 & 0.2978 & 0.0156 & 0.96 & 1.25 & 0.2 & 3.455 & 0.0169 & 4.118 \\
70 & 0.2835 & 0.0176 & 0.96 & 1.25 & 0.2 & 3.402 & 0.0178 & 3.707 \\
95 & 0.2578 & 0.0198 & 0.96 & 1.25 & 0.2 & 3.352 & 0.0180 & 3.345 \\
120 & 0.2477 & 0.0221 & 0.96 & 1.25 & 0.2 & 3.309 & 0.0189 & 3.051 \\
150 & 0.2418 & 0.0241 & 0.96 & 1.25 & 0.2 & 3.273 & 0.0199 & 2.827 \\
185 & 0.2347 & 0.0271 & 0.96 & 1.25 & 0.2 & 3.226 & 0.0215 & 2.550 \\
240 & 0.2271 & 0.0295 & 0.96 & 1.25 & 0.2 & 3.193 & 0.0224 & 2.366 \\
300 & 0.2107 & 0.0332 & 0.96 & 1.25 & 0.2 & 3.147 & 0.0230 & 2.132 \\
400 & 0.2051 & 0.0376 & 0.96 & 1.25 & 0.2 & 3.101 & 0.0250 & 1.911 \\
500 & 0.1903 & 0.0430 & 0.96 & 1.25 & 0.2 & 3.051 & 0.0261 & 1.697 \\
630 & 0.1858 & 0.0478 & 0.96 & 1.25 & 0.2 & 3.014 & 0.0280 & 1.546 \\
800 & 0.1848 & 0.0535 & 0.96 & 1.25 & 0.2 & 2.974 & 0.0308 & 1.399 \\
\hline
\end{tabular}

After deriving the values of conductor resistance, dielectric loss, and thermal resistance $\mathrm{T}_{1}$ and $\mathrm{T}_{4}$, the cable ampacities can now be calculated using (10).

$$
I=\left[\frac{\Delta \theta-W_{d}\left[0.5 T_{1}+n\left(T_{2}+T_{3}+T_{4}\right)\right]}{R T_{1}+n R\left(1+\lambda_{1}\right) T_{2}+n R\left(1+\lambda_{1}+\lambda_{2}\right)\left(T_{3}+T_{4}\right)}\right]^{0.5}
$$

\subsection{Calculation of cable ampacities using AS/NZS 3008.1.1 standard}

Although the recommended equations to determine the cable ampacities are given in IEC60287, the purpose of this calculation is to verify if (11) can be used to determine the ampacity rating of cables at $110^{\circ} \mathrm{C}$ for installation in air and whether the results can be safely utilized. Table 6 summarizes the calculated ampacities and differences between the values obtained from two Standards.

$$
\left(\frac{I_{0}}{I_{R}}\right)^{2}=\frac{\theta_{0}-\theta_{A}}{\theta_{R}-\theta_{A}}
$$

where $I_{0}$ is the operating current $(\mathrm{A}), I_{R}$ is the rated current $(\mathrm{A}), \theta_{0}$ is the operating temperature of cable when carrying $I_{0}\left({ }^{\circ} \mathrm{C}\right), \theta_{R}$ is the operating temperature of cable when carrying $I_{R}\left({ }^{\circ} \mathrm{C}\right)$ and $\theta_{A}$ is the ambient air or soil temperature $\left({ }^{\circ} \mathrm{C}\right)$.

Table 6. Calculated ampacities at $110^{\circ} \mathrm{C}$ and their differences

\begin{tabular}{cccc}
\hline $\begin{array}{c}\text { CSA } \\
\mathrm{mm}^{2}\end{array}$ & $\begin{array}{c}\text { IEC } 60287 \\
\text { Amps }\end{array}$ & $\begin{array}{c}\text { AS/NZS 3008.1.1 } \\
\text { Amps }\end{array}$ & $\begin{array}{c}\text { Difference } \\
\%\end{array}$ \\
\hline 16 & 84 & 84 & 0 \\
25 & 115 & 115 & 0 \\
35 & 141 & 141 & 0 \\
50 & 176 & 173 & 2 \\
70 & 223 & 220 & 1.4 \\
95 & 276 & 275 & 0.6 \\
120 & 325 & 321 & 1.3 \\
150 & 374 & 370 & 0.9 \\
185 & 440 & 432 & 1.9 \\
240 & 522 & 518 & 0.7 \\
300 & 613 & 601 & 1.9 \\
400 & 729 & 709 & 2.8 \\
500 & 869 & 832 & 4.3 \\
630 & 1020 & 975 & 4.4 \\
\hline
\end{tabular}




\section{DESCRIPTION OF TEST}

The laboratory facility is equipped with fully integrated and automatic induction cable cycle heating system. The system can carry out a long-term heating test of Copper and aluminum power cables and associated cable connectors with a total load current of up to 6kA. Figure 1 shows the graphical modelling of the test system that consists of the following equipment:

- Cable cycle heating test unit capable in generating up to 6kA of inductive current

- Pico technology 8 channels thermocouple data loggers and associated software

- 8 units of $\mathrm{K}$ type thermocouple assembly

- Current transformer and sensor

- Fluke 435 power analyzer

- DC resistance measuring device

- Windows PC

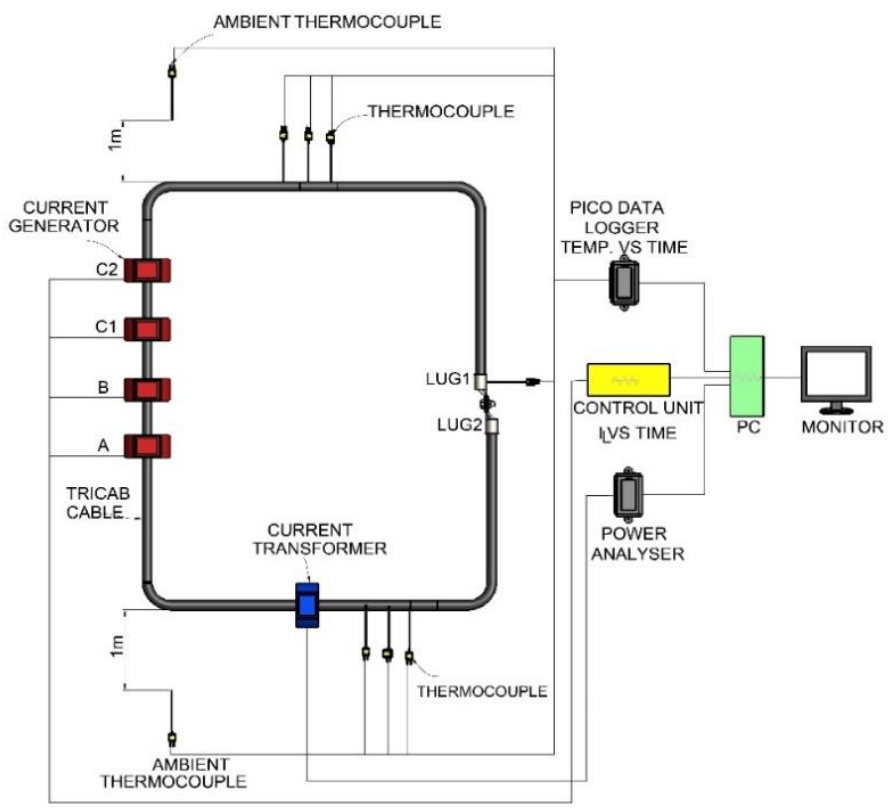

Figure 1. Graphical modelling of the heat dissipation test system

The test loop consists of three parallel X-HF-110 insulated cables with polyvinyl chloride (PVC) sheath in trefoil formation are assembled and joined in series with mechanical shear bolt connectors. Cables of 12 meters in length are placed on $450 \mathrm{~mm}$ cable ladder tray with the distance of $650 \mathrm{~mm}$ above the ground simulating the unenclosed spaced in free air condition. Cables are looped and passed in the 6000/0.1A current transformer. Cables are terminated with mechanical shear bolt connectors and sheared using a torque wrench. Conductors are polished and cleaned using a steel wire brush before inserting onto the connector. Film of conductive grease are applied between conductor and inner barrel of connector to ensure moisture penetration within the contact point are eliminated.

The palms of the two mechanical connectors are attached with a bolt to ensure a good contact point. The thermocouple leads are attached to the conductor, insulation, sheath of cable and to the body of mechanical connector. The other thermocouple lead is attached to a one-meter conductor, one meter away from the unit under test, for the measurement of ambient temperature. The resistance of connections is measured using the DC resistance meter prior to applying the current. Application of current is carried out using the current generator from the heat cycling unit. Current is tuned and adjusted based on the ambient temperature inside the test facility. The induced test currents from the current generators are verified and validated using the Fluke 435 power analyzer as seen in Figure 2. 


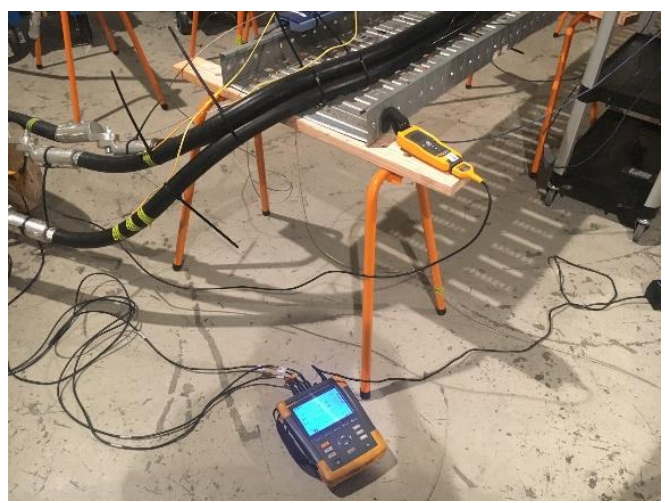

Figure 2. Induced current is measured using Fluke 435 power analyzer

The temperature rises as measured on all thermocouple leads are recorded on Pico system data logger. The requirement is that the equilibrium shall reach the point for a time sufficient for the temperature rise to reach a constant value. This condition is achieved when the variation at all measured points does not exceed $1 \mathrm{~K} / \mathrm{h}$ [19]. The joint temperature between the conductor and connector always needs to be cooler than the temperature of the conductor as temperature rise on the joints could potentially caused a premature failure of connection on the field.

\section{RESULTS AND DISCUSSION}

\subsection{Simulated current and conductor temperature}

There is a heat generated to the conductor when the current is applied. This phenomenon is called conductor loss [20] and can be calculated using (12).

$$
P_{c}=I^{2} R
$$

where $P_{c}$ is the conductor loss $(\mathrm{W}), I$ is the current flowing to the conductor (A) and $R$ is the DC resistance of conductor $(\Omega / \mathrm{km})$.

Throughout the duration of test, the current generated from heat cycling unit are verified using Fluke 435 Power Analyzer attached to each conductor of three-phase system. Current source is tuned for every rise of ambient temperature due to the heat dissipated from the unit under test. Tuning of current source are completed when the unit under test reached its equilibrium stage as defined in [21] where the temperature of conductor and connectors do not change by $\pm 2{ }^{\circ} \mathrm{C}$ for 15 minutes.

Table 8 represents the measured average conductor temperature of 50 to $630 \mathrm{~mm}^{2}$ cables across three phases due to conductor losses with respect to the ampacity rating derived in (11). Table 7 shows that the conductor temperatures are below the $110^{\circ} \mathrm{C}$ limit as used in the calculation of rated ampacity. These are the values produced in simulation test when the conductors and connectors reached their state of equilibrium.

Table 7. Measured current and temperature when the calculated ampacity is applied to conductor

\begin{tabular}{ccccc}
\hline $\begin{array}{c}\text { CSA } \\
\mathrm{mm}^{2}\end{array}$ & $\begin{array}{c}\text { Ambient temperature } \\
\text { during testing } \\
{ }^{\circ} \mathrm{C}\end{array}$ & $\begin{array}{c}\text { Rated current at } \\
\text { ambient temperature }\end{array}$ & $\begin{array}{c}\text { Measured } \\
\text { current } \\
\text { A }\end{array}$ & $\begin{array}{c}\text { Conductor temperature } \\
\text { at equlibrium } \\
{ }^{\circ} \mathrm{C}\end{array}$ \\
\hline 50 & 19 & 195 & 197 & 104 \\
70 & 22 & 249 & 250 & 105 \\
95 & 23 & 311 & 311 & 106 \\
120 & 20 & 363 & 367 & 107 \\
150 & 24 & 407 & 414 & 105 \\
185 & 23 & 475 & 475 & 106 \\
240 & 24 & 577 & 577 & 109 \\
300 & 31 & 643 & 643 & 109 \\
400 & 24 & 759 & 760 & 105 \\
500 & 25 & 915 & 915 & 105 \\
630 & 26 & 1073 & 1077 & 108 \\
\hline
\end{tabular}




\subsection{Temperature at connection point}

The temperature measured at the connection points of various cable sizes from six thermocouples are between 62 to $72{ }^{\circ} \mathrm{C}$ when the rated ampacity is applied to the conductors. This is an evidence that the shear bolt connectors are averaging $39^{\circ} \mathrm{C}$ cooler than the phase conductors and are consistent across all cable samples. The highest recorded connector temperature was $72{ }^{\circ} \mathrm{C}$ on 240 and $630 \mathrm{~mm}^{2}$ and were low on 50 , $70,95,120$ and $150 \mathrm{~mm}^{2}$. The high cross-sectional ratio of connector and conductor presented in Table 8 contributes to the cooler termination point.

Table 8. Conductor: Connector cross-sectional ratio

\begin{tabular}{ccc}
\hline $\begin{array}{c}\text { Conductor cross- } \\
\text { sectional area } \\
\mathrm{mm}^{2}\end{array}$ & $\begin{array}{c}\text { Connector barrel cross - } \\
\text { sectional area } \\
\mathrm{mm}^{2}\end{array}$ & CSA Ratio \\
\hline 50 & 324 & 6 \\
70 & 419 & 6 \\
95 & 419 & 4 \\
120 & 541 & 5 \\
150 & 541 & 4 \\
185 & 575 & 3 \\
240 & 575 & 2 \\
300 & 1000 & 3 \\
400 & 1000 & 3 \\
500 & 1391 & 3 \\
630 & 1656 & 3 \\
\hline
\end{tabular}

\subsection{Temperature of insulation and sheath}

Thermal resistivity of polymeric material influenced the heat transmitted from conductor to air. Cables are subjected to electrical losses during its service and operation and these losses transform to heat that dissipate from conductor to the insulation, sheath, and metallic layers. The resultant heat dissipated from cables affects the ambient temperature of the surrounding medium which then influence the ampacity rating of cable in the form of derating factor [22]. Figure 3 represents the heat dissipated to every layer of cable samples under test taken from Pico data logger for the duration of tests. The heat dissipated from sheath of all cable samples measured from the three thermocouples were less than $90{ }^{\circ} \mathrm{C}$ which is below the maximum operating temperature of PVC material at steady state condition [22].

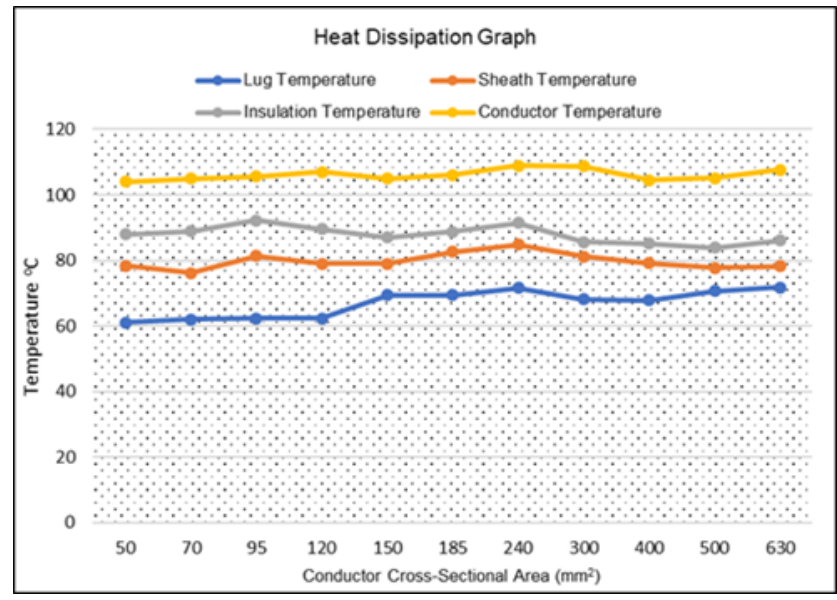

Figure 3. Graph of heat dissipated to termination, conductor, insulation, and sheath

\section{CONCLUSION}

The recorded conductor temperature with respect to the calculated rated ampacity for the threephase conductors are found to meet the value for the $110^{\circ} \mathrm{C}$ operating condition. The results of the simulation tests are very encouraging and gave the authors a confident level that the calculated ampacities derived from (10) are suitable for use in electrical system that operates at $110{ }^{\circ} \mathrm{C}$ maximum operating temperature. The simulated ampacities when compared with the ampacities derived from IEC60287, the typical method in 
calculating ampacities of cables, are found to be within the $5 \%$ acceptable limit with majority of the differences are less than $2 \%$.

The analysis of the heat dissipation test between the mechanical shear bolt connectors and Class 5 flexible aluminum conductors also confirms the initial suitability of mechanical shearbolt connectors due to the low joint temperature that averages about $30{ }^{\circ} \mathrm{C}$ lower than the conductor temperature that eliminates the lateral expansion at the termination point. Results of the heat dissipation test shows that the connectorconductor cross-sectional area ratio tends to influence the temperature at termination point: lower tempretuare for high ratios about 4-6 whereas high temperature for low ratios of about 2-3. Maintaining a low temperature at connection point is vital to the reliability of termination for the aluminum conductor. Authors are now investigating the final suitability of mechanical shear bolt connectors when the cables are experiencing electrical fault.

\section{ACKNOWLEDGEMENT}

The authors would like to express their gratitude to Victoria University for granting the scholarship for this research project.

\section{REFERENCES}

[1] W. A. Thue, Electrical Power Cable Engineering, 3rd ed, Boca Raton, FL, USA: CRC Press, pp. 23-51, 2012.

[2] T. Yi, J. Liao, B. Chen, Z. Zhu, S. Lu and B. Gao, "Life Cycle Cost based modeling and economic evaluation of 10 $\mathrm{kV}$ aluminum alloy power cables," 2016 IEEE International Conference on Cyber Technology in Automation, Control, and Intelligent Systems (CYBER), 2016, pp. 162-166, doi: 10.1109/CYBER.2016.7574815.

[3] Conductors in Insulated electric cables and flexible cords, AS/NZS 1125, Australian Standard/New Zealand Standard, 2001.

[4] Conductors of insulated cables, IEC 60228, International Electrotechical Commission, Geneva, Switzerland, 2004.

[5] A. Kalam, H. Al-Khalidi and D. Willen, "HTS cable and its anticipated effects on power transmission networks," The 8th IEE International Conference on AC and DC Power Transmission, 2006, pp. 50-53, doi: 10.1049/cp:20060011.

[6] H. Al-Khalidi, A. Hadbah and A. Kalam, "Performance analysis of HTS cables with variable load demand," 2011 IEEE PES Innovative Smart Grid Technologies, 2011, pp. 1-8, doi: 10.1109/ISGT-Asia.2011.6167083.

[7] Electrical Installations Part1. 1: Cables for alternating voltages up to and including 0.6/1kV-Typical Australian installation conditions, AS/NZS 3008.1.1, Australian Standard/New Zealand Standard, 2017.

[8] S. Curreli et al., "Evaluation of the Effects of Mechanical Cycles on Bonding of Al-Superconducting Cable in High-Performance Stabilized NbTi Conductor," in IEEE Transactions on Applied Superconductivity, vol. 27, no. 4, pp. 1-4, June 2017, Art no. 4802004, doi: 10.1109/TASC.2016.2646067.

[9] M. Guthrie, G. Martinjak and H. B. VanSickle, "IEC 62561 electrical testing of US connectors and stranded cable," 2016 33rd International Conference on Lightning Protection (ICLP), Estoril, Portugal, 2016, pp. 1-9, doi: 10.1109/ICLP.2016.7791404.

[10] A. Ramonat, S. Schlegel, S. Großmann and M. Kudoke, "Basic investigations on joints with cylindrical aluminum conductors made by press- and shrink-fit for high-current devices," 2015 IEEE 61 st Holm Conference on Electrical Contacts (Holm), San Diego, CA, USA, 2015, pp. 309-316, doi: 10.1109/HOLM.2015.7355114.

[11] K.-D.Haim, D. Cisilino and K.-U. Bentkowski, "The behaviour of shear bolt connectors in MV - Cable accessories in case of critical load and overload," in CIRED 2009 - 20th International Conference and Exhibition on Electricity Distribution - Part 1, no. 0285, 2009, doi: 10.1049/cp.2009.0660.

[12] K.-D. Haim, R. Bärsch, J. Pilling and J. Hofmann, "The compact joint with integrated shear bolt connector: A new approach to function integration in medium voltage joints," in CIRED 2005 - 18th International Conference and Exhibition on Electricity Distribution, 2005, pp. 1-5, doi: 10.1049/cp:20050945.

[13] M. Runde, H. Jensvold and M. Jochim, "Compression connectors for Stranded aluminum power conductors," in IEEE Transactions on Power Delivery, vol. 19, no. 3, pp. 933-942, Jul. 2004, doi: 10.1109/TPWRD.2004.829946.

[14] W. B. Haverkamp, T. McKoon and M. Wilck, "Bolted connectors for high voltage accessories installed on underground transmission lines," 1999 IEEE Transmission and Distribution Conference (Cat. No. 99CH36333), New Orleans, LA, USA, vol. 1, pp. 74-82, 1999, doi: 10.1109/TDC.1999.755319.

[15] D. C. Giancoli, "Thermal Expansion," Physics for Scientists \& Engineers with Modern Physics, 4th ed, vol. 1, Upper Saddle River, New Jersey: Pearson Education, 2009, pp. 459-463.

[16] Moore, G. F, "Thermomechanical design," Electric Cables Handbook, 3rd ed. vol. 1. Oxford: Blackwell Science Ltd, 1997, pp. 562-573.

[17] Electric cables-Calculation of the current rating Part 1-1: Current rating equations (100\% load factor) and calculation of losses-General, IEC 60287-1-1, Internatonal Electrotechnical Commission, Geneva, Switzerland, 2006.

[18] Electric cables-Calculation of the current rating Part 2-1: Thermal resistance - Calculation of thermal resistance, IEC 60287-2-1, Internatonal Electrotechnical Commission, Geneva, Switzerland, 2006.

[19] Low voltage switchgear and controlgear assemblies Part1: General rules, IEC 6149-1, ed. 2.0, International Electrotechical Commission, Geneva, Switzerland, pp. 64-71, 2011. 
[20] T. Wildi, Electrical machines, drives, and power system, 6th ed. Upper Saddle River, New Jersey: Pearson Education, 2006, pp. 120-131.

[21] Compression and mechanical connectors for power cables - Part1-1: Test methods and requirements for compression and mechanical connectors for power cables for rated voltages up to $1 \mathrm{kV}(U \mathrm{~m}=1.2 \mathrm{kV})$ tested on noninsulated conductors, IEC 61238-1-1, International Electrotechnical Commission, Geneva, Switzerland, 2018.

[22] Wiring rules, AS/NZS 3000, Australian Standard/New Zealand Standard, 2018.

\section{BIOGRAPHIES OF AUTHORS}
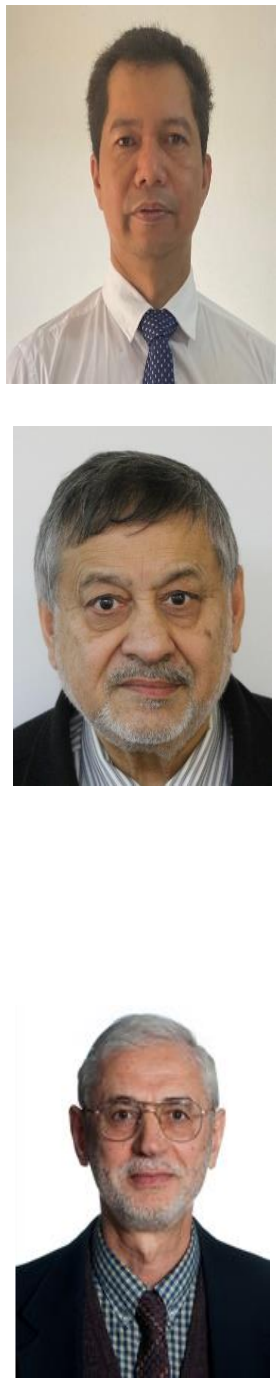

Fernando Esma Agustin received his Bachelor of Engineering with Honours in Electrical Engineering from Victoria University, Melbourne, Australia in 2010, where he is currently pursuing his PhD degree. He is the former Technical Manager of TriCab, Australia, from 2010 to 2019 in-charged of Technical and R\&D Team. His research interest includes design and reliability of cabling system.

Professor Akhtar Kalam has been at Victoria University (VU), Melbourne since 1985 and a former Deputy Dean of the Faculty of Health, Engineering and Science and Head of Engineering of the College of Engineering and Science. He is currently the Head of External Engagement at the College of Engineering and Science, VU. He is also the current Chair of the Academic Board in the Engineering Institute of Technology, Perth, Australia. Again, he is the Editor in Chief of Australian Journal of Electrical \& Electronics Engineering. $\mathrm{He}$ has wide experience in educational institutions and industry across four continents. He received his B.Sc. and B.Sc. Engineering from Calcutta University and Aligarh Muslim University, India. He completed his MS and Ph.D. at the University of Oklahoma, USA and the University of Bath, UK. He has conducted research, provided industrial consultancy, published over five hundred publications on his area of expertise. More than 42 research degree students have graduated under his supervision and he is an external examiner of many external doctoral students in Australia and overseas. He provides consultancy for major electrical utilities, manufacturers and other industry bodies in his field of expertise. Professor Kalam is a Fellow of EA, IET, AIE, a life member of IEEE, NER, APEC Engineer, IntPE (Aus) and a member CIGRE AP B5 Study Committee.

Associate Professor Aladin Zayegh had been at Victoria University, Melbourne, Australia since 1984 and former head of School of Electrical and Electronic Engineering for five years and research director where he has conducted research, supervised several $\mathrm{PhD}$ and Master Degree students and published more than 360 Papers, books chapters, in peer reviewed International Conferences and Journals. received his BE degree in Electrical Engineering from Aleppo University in 1970 and Ph.D. degree from Claude Bernard University, Lyon, France in 1979. He is currently Adjunct Professor at the College of Engineering and Science, Victoria University, Melbourne, Australia. His research interest includes Renewable energy, instrumentation, data acquisition. He is a Member of several Professional Institutions EA, CPEng, NER, APEC, a life member of IEEE. 